\title{
The Effects of Logotherapy on Depression in People with HIV / AIDS (ODHA)
}

\author{
Sri Burhani Putri, Welly
}

\begin{abstract}
Background: It is very important to pay attention to the quality of life in HIV / AIDS patients because this infectious disease is chronic and progressive so that it has a wide impact on all aspects of life, whether physical, psychological, social, or spiritual. Logotherapy is a therapy that can be used for patients with depression. Methods: The design of this study was a quasi-experimental pre-post control group with the aim of seeing changes in the depressive condition of HIV / AIDS patients before and after being given logotherapy. Data collection was carried out using the Cronic Epidemiological Depression Scale (CESD) instrument and the University of Indonesia Mental Nursing Therapy Module. Results: The results showed the mean value for depression in people with HIV / AIDS in this study was 22.34 (SD = 5,827) before being given logotherapy and the mean value for depression in people with HIV / AIDS in this study was 18.04 (SD = 3,217) after being given logotherapy. Conclusion: There is a significant difference between depression levels of people with HIV/AIDS (ODHA) before and after logotherapy intervention.
\end{abstract}

\section{Index Terms-HIV/AIDS, logotherapy, depression}

\section{INTRODUCTION}

HIV / AIDS patients face multiple stressors, namely their physical condition that decreases with the course of the disease, the social pressures they face, fear of death due to illness, and family and economic problems. With these complex stressors, patients often cannot develop adaptive coping, so they fall into a state of depression. Depression will make patients pessimistic about the future, view themselves as worthless, tend to shut themselves up and don't want to hang out with other people, and think of themselves as people who are cursed by God.(1)

One of the therapies that can be given is logotherapy. FIK UI in the mental nursing therapy module, states that logotherapy can be applied to patients with coping problems in terminal chronic diseases, coping in chronic physical diseases, grieving or mourning processes, depression, post traumatic syndrome disorder (PTSD), stress management, disorders personal, phobias and psychogenic neurotic disorders.(2)

Logotherapy has been shown to reduce depression. Logotherapy can reduce depression in women with domestic violence. Tthere is an effect of logotherapy on the meaning of life in the elderly. Tthat after being given medical ministry logotherapy there was an improvement in depression and quality of life in HIV / AIDS patients.(3)

Sri Burhani Putri, Nursing Study Program, West Sumatera chool of Health, Lubuk Alung, West Sumatera Province, Indonesia

Welly, Nursing Study Program, Alifah School of Health, Padang, West Sumatera Province, Indonesia

\section{MATERIALS AND METHODS}

\section{A. Study Design and Research Sample}

The design of this study was quasi-experimental pre-post with control group. The study was conducted at Akbar Foundation, Padang City, West Sumatera Province, Indonesia. Sample size 38 people with two groups consist depression and not. Data collection was carried out using the instrumen Cronic Epidemiolgy Depression Scale (CESD) and the University of Indonesia Mental Health Nursing Therapy Module. Test the normality of data by Shapiro-Wilk test and hypothesis test using paired $\mathrm{t}$ test. A two-tailed $P$-value of $<0.05$ was considered statistically significant.(4)

\section{B. Operational Definitions}

The variables of this study included independent variable is logotherapy intervention and dependent variable is depression in people with HIV/AIDS (ODHA).

\section{Data Collection Technique}

The instrument used in this study was Cronic Epidemiolgy Depression Scale (CESD) and mental nursing therapy module NERS Study Program Psychiatric Nursing Specialist Faculty of Nursing University of Indonesia as a guideline for implementing logotherapy consisting of 4 sessions, including fostering trusting relationships, identifying patient response and response to problems, medical ministry and evaluation technique. Pretest session, at this stage the depression of people with HIV/AIDS (ODHA) were measured using the CESD instrument for all 38 respondents. The stages of intervention, at this stage the respondents were divided into 2 groups, namely the intervention group and the control group with a total of 19 people for each group. In the intervention group there were 4 sessions of logotherapy and in the control group no logotherapy was given. One week after the last session was completed, depression measurements were carried out in the intervention group and the control group using the CESD instrument and leaflets were given about depression management.

\section{D.Data Analysis}

The quantitative variables were recorded as Mean $\pm \mathrm{SD}$, median and percentage. Test the normality of data by Shapiro-Wilk test and hypothesis test using paired $t$ test. 
A two-tailed $P$-value of $<0.05$ was considered statistically significant. A two-tailed $P$-value of $<0.05$ was considered statistically significant. Data were analyzed using the Stata version 14.2 (Stata Corporation).

\section{RESULTS}

Descriptive Depression of Respondents People with HIV / AIDS (PLWHA) Before Logotherapy Given (Table 1)

Table 1: Distribution of Depression in People Living with HIV / AIDS (ODHA) Before Logotherapy

\begin{tabular}{ccccc}
\hline Variabel & Mean & SD & Min-Max & 95\% CI \\
\hline Depresi & 22.34 & 5.827 & $16-40$ & $19.39-21.89$
\end{tabular}

Table 1 showed that the mean value for depression in people living with HIV / AIDS in this study was 22.34 (SD = 5,827).

Descriptive Depression of Respondents of People with HIV/AIDS (ODHA) After Being Given Logotherapy (Table 2)

Table 2: Distribution of Depression in People with HIV / AIDS (ODHA) After Logotherapy

\begin{tabular}{ccccc}
\hline Variabel & Mean & SD & Min-Max & 95\% CI \\
\hline Depresi & 18.04 & 3.217 & $12-28$ & $19.39-21.89$ \\
& & & & \\
\hline
\end{tabular}

Table 2 showed that the mean value for depression in persons with HIV/AIDS in this study was 18.04 ( $\mathrm{SD}=3,217)$.

\section{DISCUSSION}

The result showed there was an effect of logotherapy on depression in people with HIV/AIDS (ODHA) $(\mathrm{p}<0.05)$. Study showed that anxiety and depression decreased significantly after logotherapy ( $\mathrm{p}$-value $=0.000$ for the anxiety variable and $p$-value $=0.002$ for the depression variable).(3)

Research showed that logotherapy can reduce depression in women with domestic violence. An effect of logotherapy on the meaning of life in the elderly. After being given medical ministry logotherapy there was an improvement in depression and quality of life in HIV / AIDS patients.(5)

Reaching for a meaningful life is the main motivation for humans. Logotherapy is a form of psychotherapy used by depressed patients to find the meaning of life in the suffering they experience. Logotherapy emphasizes the principles of human life to achieve meaningful life, where happiness is the main motivation of humans.(6)

\section{CONCLUSION}

The onclusion of this study confirmed there was an effect of logotherapy on depression people with HIV/AIDS (ODHA).

\section{ACKNOWLEDGMENT}

We would like to thank all respondents who participated in this study.

\section{REFERENCES}

[1] 1. Minrie Greef. Perceived HIV stigma and life satisfaction among persons living with HIV infection in five African countries: A longitudinal study. Int J Nurs Stud [Internet]. 2010;47(4):475-86. Available from: https://www.ncbi.nlm.nih.gov/pmc/articles/PMC3624763/pdf/nihms4 12728.pdf

[2] 2. Tran BX, Dang AK, Truong NT, Ha GH, Nguyen HLT, Do HN, et al. Depression and quality of life among patients living with HIV/AIDS in the era of universal treatment access in Vietnam. Int $\mathbf{J}$ Environ Res Public Health. 2018;15(12):1-14

[3] 3. Fitriana QA, Rochman Hadjam MN. Meraih Hidup Bermakna: Logoterapi untuk Menurunkan Depresi pada Perempuan Korban KDRT. Gadjah Mada J Prof Psychol. 2016;2(1):26.

[4] 4. Polit DF and CTB. Nursing research: principle and methods. Philadelpia: Lippincott Williams \& Wikins; 2012.

[5] 5. Muhammad Saleh Nuwa, Stefanus Mendes Kiik ARV. Penanganan Terhadap Stigma Masyarakat tentang Orang Dengan HIV/AIDS (ODHA) di Komunitas. J Penelit Kesehat Suara Forikes [Internet]. 2019;10(1):49-54. Available from: http://forikes-ejournal.com/index.php/SF

[6] Putit Z, Fernandes F. The Relation Between Respondent Charactersitic and Depression with Life Quality of People with HIV/AIDS. Elev Int J Nurs Educ Pract Res. 2018;1(1):22-45. 